ISSN 1822-8402 EUROPEAN INTEGRATION STUDIES. 2014. №. 8

\title{
INSIGHT INTO RELEVANT TO THE EU GLOBALISATION AND MARKET DEVELOPMENT PROCESSES AFTER THE SECOND WORLD WAR
}

\author{
Stanislavs Keiss \\ The University College of Economics and Culture \\ Lomonosova 1/5, Rìga, LV-1019, Latvia \\ e-mail:s.keiss@eka.edu.lv \\ Elga Tilta \\ Institute of Economics of the Latvian Academy of Sciences \\ Akadèmijas laukums 1, LV-1050, Rīga, Latvia \\ e-mail:elgatilta@inbox.lv \\ Gunta Balode \\ Latvian Rural Advisory and Training Centre \\ Rigas str. 34, LV-3018, Ozolnieku district, Latvia \\ e-mail: gunta.balode@gmail.com
}

cross' $^{\text {ref }}$ http://dx.doi.org/10.5755/j01.eis.0.8.6832

The purpose of the study is to analyse the topicalities and specifics of globalisation and market development processes since the Second World War until the end of the $20^{\text {th }}$ century, in the context of their impact on urgent problems related to development of economic thought.

To achieve the aim, the following tasks were fulfilled:

1) to study historical events related to development of the market economy;

2) to analyse the changes, caused by historical processes, in economic theory under the conditions of globalisation;

3) to find solutions related to research problems in the area of economic thought.

The following methods were used in the study: monograph, historical study, synthesis and analysis, logical-constructive method, analysis of historical facts and statistical data.

In the study of historical events, mainly on the basis of the monograph and historical study methods, the attention was, generally, paid to different changes the world had experienced since the Second World War: such as the development of globalisation processes, having taken their beginning already during the Second World War; the more and more rapid rotations, taken up by globalisation processes; the sharp getting up of market regulation; the more and more visible role played by anew established cross border political, financial, military and economic organisations.

In the analysis of the changes in the economic theory the attention was, on the basis of synthesis and analysis, logicalconstructive method and others, paid mainly to the domination of the cyclic economic development, being recognised, in the economic theory, as a self-evident norm also under conditions of the globalisation; to the beginning of domination of political relations over economic regularities in the society; to the tendency of endeavour to explain the economic relations with mathematical-statistical methods (Keišs, S., 2012: 52; Krilovs, L., 2003:151-155).

As a result of the research, the authors have tried to find ways how to substantiate the changes in economic theory and in the policies of the countries of market economy under the conditions, when there takes place a declaratively propagated support to the liberalism and to democratic values, but, in the real life, a tendency of a growing dominance of regulation of the market processes may be observed. Latvia, as a post-socialism country, is especially interested in finding of the necessary attitude in this context.

Keywords: globalisation, cross border organisations, regulation of market processes, economic development, changes in economic thought.

\section{Introduction}

Since the end of the $18^{\text {th }}$ century until the $1930^{\text {th }}$ the history of the development of economic thought has been made richer by innovative search in the study of regularities of development of the society. However, it must be recognized that, under the conditions of market economy, the cyclic economic development and financial economic crises are explained as self-evident. And, during the last century, little has been achieved in this area, and the study of it is still a challenge to economic science.

If earlier, it has been accustomed to speak about the cyclic crises of overproduction, being typical to market economy, then, under the impact of globalisation the today reality evidences that they have turned into consumption crises of 
a chronic nature. Insolvency problems are faced not only by the business companies and households, but even by national states (Keišs, S., 2012: 54; Krilovs, L., 2008: 33-36). Such is the reality of the first decade of the $21^{\text {st }}$ century.

It all evidences that, since the 1920s, in the development of economic theory, there takes place a lack of new approaches in the research area related to economic theory. The innovative approach is still insufficient in the study of economic processes, regularities and legislation of the society. It is confirmed, solely, by the last financial economic crisis of the 2008, because the causes of the crises are to be related to an excessive stimulation of consumption by a great many of the countries of market economy that is incommensurable with the increase of the productivity in the economy on the whole. The emergence of disproportions between the consumption and the economic growth rate of the countries is related, in a most direct way, to the crediting policy carried out by the institutions of financial market, by stock exchanges and the banks. The motivation of a maximal profit-making, which influences, essentially, the mortgage crediting amounts and an inadequate increase in the value of immovable property, in comparison with their real market value, dismantled, in point of fact, the regularities of demand and supply, existing in a free market economy (Keišs, S., 2012: 54; Kučinskis, J.,2000: 212-216).

The Second World War changed the economic, political and social situation in the world and the Europe significantly, involving the national states into overcoming of the implications created by the War.

In the process of overcoming of the implications of the War, the society was confronted with such phenomenon as a more and more rapid rotations of globalisation processes, having taken their begin already during the Second World War, as well as a sharp increase related to market regulation processes.

Due to the financial economic crisis of the 1929-1933, as well as the Second World War, the destroying implications of which was pressed to experience the society, there turned up, in the global processes, a line of activities (Galbraith, J.K., 1988). The United Nations Organisation (UNO) was established. At the Monetary and Financial Conference, organized by the UNO in Bretton Woods (New Hampshire State, USA) in July, 1944, there was discussed the topic related to cessation of activity of the Latin Coin Union, because, during the interwar period, the gold standard had lost, gradually, its role in cross border payments (Latvijas, 1984: 728). When the Bretton Wood Agreement came into effect in the 1944, as the principal currency of the Bretton Wood Monetary System became recognized the dollar, being, at the same time, the main reserve currency.

As a result of the above mentioned conference, and according to the agreement, adopted by 44 representatives of the states (without USSR) (Politiskā 1987: 38), there were established the International Monetary Fund (IMF) and the International Bank for Reconstruction and Development (IBRD), later called World Bank (WB).

In 1947, the General Agreement on Tariffs and Trade (GATT) was established. The aim of the GATT, which later was changed into the World Trade Organisation (WTO), was to facilitate the free market and to decrease the tariffs all over the world, to restrict the protectionism and interference of the state into regulation of the market processes. The WTO began to function on January 1, 1995 (Šreters, H. J., 2004: 141-142).

In 1973, the Breton Wood Monetary System ceased to function (Latvijas 1982: 2.sējums, 134). Taking into consideration that the US dollar began to lose its role as the means of international payments rapidly, the USA interrupted, in the 1971, one-sidedly, the exchange of the dollar against the gold. With the breakdown of the Bretton Wood Monetary System (1971-1973), there ceased to exist also the official gold market and the centralized gold reserves of the state could get into the free market only (Vēciňš, E.

Since the 1978, the Jamaica Monetary System started to regulate the monetary and financial relations on the global scale (Latvijas, 1982: 134). The Jamaica Monetary System was established in 1976 in Kingston (Jamaica) on the basis of the agreement attained by the International Monetary Fund (IMF) because of the reform of international monetary system.

The implications of the Second World War changed the economic situation in Europe essentially. There were formed both economic and political alliances, as well as military alliances. In the post-war period, there developed, on the basis of the agreements between the USSR and the Germany (Molotov-Ribbentrop Pact), a dangerous aggressive socialist area in the East of the Europe - the USSR, and, as a result, a line of the countries of the League of Nations lost their national independence (inter alia Latvia, Lithuania, Estonia). But, in the post-war period, because of retaining of the soviet armed forces in the occupied East European countries, the social revolution took place in them, and, as a result, they were turned into satellites of the socialism system. Very soon, there began the rivalry of two political systems related to re-division of the influence in the world. The cold war continued until the collapse of the Berlin wall. With the collapse of the Berlin wall, in 1989, and uniting of both states of the Germany, there began, in point of fact, a decline of the communist ideology and the existence of the USSR, the introducer of that ideology.

All these processes have left, in the turn of the century, an intransient impact on the development of the society and the economic theory.

The purpose of the study is to analyse the topicalities and specifics of the globalisation and market development processes since the Second World War until the end of the $20^{\text {th }}$ century in the context of their impact on urgent problems related to development of the economic thought.

To achieve the aim, the following tasks were fulfilled:

1) to study historical events related to development of the market economy;

2) to analyse the changes, caused by historical processes, in economic theory under conditions of the globalisation;

3) to find solutions related to research problems in the area of economic thought.

The research object is globalisation challenges and specifics of market development process since the Second World War until the changes in the end of the $20^{\text {th }}$ century.

The following methods were used in the study: monograph, historical study, synthesis and analysis, logical-constructive method, analysis of historical facts and statistical data. 


\section{Discussion and Results}

Economic Cross-Border Organisations Established During the Second World War and the Earlier After-War Period and their Role

In that time, a typical feature in the development of market processes was the formation and activities of cross border political organisations.

To the most important cross border political organisations, the aim of which was to overcome the implications of the Second World War and to facilitate the development of the market processes under conditions of globalisation, belong the United Nations Organisation (UNO), the International Monetary Fund (IMF), the International Bank for Reconstruction and Development (IBRD), later the World Bank (WB), the General Agreement on Trade and Tariffs (GATT), later the World Trade Organisation.

In this period, there was born the idea, involving the establishment of the United Nations Organisation (UNO). The beginning of the UNO is to be sought on January 1, 1942, when the representatives of 26 states signed, in Washington, the Declaration of United Nations, in which they agreed to form a common war alliance against the Hitler's ass countries (Germany, Italy, Japan) (Politiskā 1987; 32). However, the resolution of establishment of the United Nations Organisation was adopted only on October 30, 1943. The aim of this organisation was to provide support, peace and international security, as well as the development of cooperation between the countries (Politiskā 1987; 32). In fact, the UNO was a replacement of the League of Nations that was established after the First World War at the Paris Peace Conference, in 1919, and with signing of its statutes by 44 countries. The USA had not been a member of the League of Nations. The establishment of the League of Nations was linked to the break down of German, Russia, EastHungarian and Ottoman Empires, as well as to facilitation of the formation of new national states. Actually, the League of Nations ceased its activities in the 1939, but, formally, it was liquidated in April, 1946 (Politiskā 1987: 682).

It is worth to be mentioned that, already before the beginning of the Second World War, not only the USA, but also the Great Britain, France, Germany and USSR started to demonstrate themselves as super powers. During the period between the wars, the League of Nations was not able to restrict the expression of the selfish interests, shown by these European countries. The inability of the League of Nations became apparent. Already in the 1930s, it was obvious that the League of Nations would not be able to prevent the Second World War in the Europe (Deksnis 1996: 20-21).

During the Second World War, at the Monetary and Financial Conference, organized by the UNO in Bretton Woods (New Hampshire State, USA) in July, 1944, there was discussed the topic on cessation of the activity of the Latin Coin Union, taking into consideration that during the interwar period, the gold standard had, gradually, lost its mission and its role in cross-border payments had decreased to the lowest notch.

The Latin Coin Union, established by France, Belgium, Switzerland and Italia in the 1865, was based on the frank, and it was allowed to its member states to mint the gold and silver coins. Although this union came to a halt in the
1926, the monetary bimetallism system, in the form of gold and silver coins, continued to exist in several countries. In Latvia, for example, its defined gold coverage of the national currency, LVL - 0.2903226 grams - was taken into account even until the 1936.

Since the 1944, when the Bretton Woods Agreement came into effect, the US dollar was recognized as the principal currency of the Bretton Wood Monetary System. It was, simultaneously, also the main reserve currency. All cross border transactions with the gold got, actually, reduced on exchange of the gold against the US dollars, with the mediation of the New York Reserve Bank (Vēcinš 1993: 136). According to all national currencies, there was defined the gold content (a fixed number of grams), but as to the international payments they were based on a fixed exchange rate of the currency. Every country, involved in this system, evaluated its monetary unit in the gold or in the US dollars that provided the stability of the currency of these countries and eased the mutual cross border payments.

On the basis of the agreement of Bretton Woods Monetary and Finance Conference the so called Bretton Woods Monetary System was formed. The Bretton Woods Monetary System outlined the fact that a currency system of cross border regulation was created in the world. In result of the above mentioned conference, in compliance with the agreement adopted by 44 representatives of the states (without USSR) (Politiskā 1987: 38), there were established the International Monetary Fund (IMF) and the International Bank for Reconstruction and Development (IBRD), later called the World Bank (WB).

The International Monetary Fund was established with the conviction that a common activity on the level of the world is necessary to facilitate the stability of economy, like as the UNO was established with the conviction that a common action on the level of the world is necessary to provide the political stability.

In the 1944, the International Monetary Fund was entrusted with the task to provide economic stability after the Second World War and to rescue the world from new global economic catastrophes in the future. The IMF was recognized as a cross border political organization, the statute and regulating norms of which were obligatory to be taken into account by all independent countries and their central banks. The International Monetary Fund was authorized to carry out an international pressure also on such countries that would not fulfil their commitments related to an adequate maintaining of the total demand in the world. It was planned that the IMF could, in the form of loans, support also the provision of the liquidity of the balance of payments for the countries, being affected by economic recession or being not able to provide the facilitation of the total demand in the world on account of their own resources only (Stiglics 2010: 19).

The IMF was established as a social institution, the finances of which were formed by instalments of the constitutors. To a certain degree, the IMF functions like a joint stock company: its share capital is formed by instalments of the member states at the moment of signing of the capital. With enlargement of the number of member states of the IMF, the instalments into the Fund are paid, without any exception, by all member states of the IMF. Actually, the IMF is functioning as a profit organisation. Of course, it does not fulfil the functions of the 
governments of the countries of the world, therefore it does not give also an account to the citizens of the countries, which are financing it (the instalments of the countries, as it is well known, are carried out from the money of taxpayers); it does not also give account to inhabitants of the countries, the life of which it influences. The IMF communicates only with the prime ministers, ministers of finance and the central banks of the member states.

The Statute of the IMF defines that the member states have to provide a free and unrestricted exchange of their currencies and that they have to inform the IMF about the changes in the financial and monetary policy that might influence the economy of other countries. With accession to the IMF, the member states bound themselves to adapt their policy to its recommendations. However, the IMF is not an institution of the primary loan. Such functions are delegated to the World Bank. The IMF is the first and principal overseer of the monetary and currency exchange policy and it follows how it becomes taken into account. The surveillance is carried out with the help of consultants, who analyse the economic and financial situation in the member states and consult their Governments (Bojārs, Vilne, 1996: 15).

For a close cooperation with the IMF, the International Bankfor Reconstruction and Development was established, the tasks of which include the analysis of economic development tendencies of the countries - the members of the Bank, to provide a consultative support and, in the case of necessity, to provide the countries also with the loans. During the first post-war decade, the International Bank for Reconstruction and Development financed the restoration of the war-torn economy. Only during the period 1948-1951, about 13 billion US dollars were invested into the war-torn European economies that today would correspond to a 130 billion US dollar equivalent (Čangs 2011: 105). When the Europe gained strength, the International Bank for Reconstruction and Development turned their attention to the financing of development of the poorest countries of the world (Bojārs, Vilne 1996: 13).

The Bretton Woods Conference discussed also another, not less important, question related to stabilisation of the finances and to development of the international trade. The Bretton Woods Agreement invited to establish also a third international economic institution - the World Trade Organisation that would manage the international trade relations, similarly as the International Monetary Fund was entrusted with the management of international financial relations (Stiglics 2010: 22). Already at that time, the participants of the Conference were aware that there was a necessity of such international organisation that would be able to stimulate a free flow of goods and services in international transactions and to provide the development of a liberal trade, similarly, as it had been before the First World War and continued until the middle of the 1920s. However, the establishment of such organisation was not as successful as it had been intended. It was caused by the circumstance that, in the post-war period, the political reality turned out to be quite another as expected, and to disregard it could not even the biggest players of the global economy such as the USA, Great Britain, France and others.

As it is well known, already after the First World War, the countries, responding to the instability of the world's economy, started a creating of trade barriers. The free trade system of the world ceased to exist in the 1932, when Great Britain, beforehand a consequent protector of a free trade, introduced the tariffs. Before that time, already in the 1930, the USA, with introducing of the tariffs, abandoned the free trade system, but such countries as Germany and Japan changed their liberal trade policy, creating high trade barriers and cartels that were closely related to the fascism ideology and to the keeping of foreign aggressiveness (Čangs 2011: 51).

In 1947, there followed the General Agreement on Tariffs and Trade (GATT). The aim of the GATT was to facilitate the free market and to decrease the tariffs all over the world, to restrict the protectionism and the interference of the state into the regulation of market processes. Later, the GATT was changed into the World Trade Organisation (WTO). The WTO began to function on January 1, 1995.

If the Second World War destroyed the order of the first liberal world also in the sphere of the international trade, then, in the post-war period, there were started the activities to restore the economic routine that had functioned during the years of the gold liberalism. In this advance, a historically significant progress in liberalisation of the trade between the rich countries was achieved during the early negotiations related to the General Agreement on Trade and Tariffs (GATT). However, in the majority of the countries, the policy of protectionism and state interference into regulation of trade processes still continued, inter alia, in the developing and communism countries (Čangs 2011: 51).

The GATT or the General Agreement on Tariffs and Trade was instituted only in the 1947. The aim of the GATT was to facilitate a free trade and to diminish the tariffs all over the world. One of the functions of the GATT was to facilitate the diminishing of the tariffs between the countries with the highest status of a preferential treatment, the other - to allow the member states to protect their economy against an unfair foreign competition, through enforcing of antidumping means and duties against the subsidising of the export. Although the GATT succeeded in lowering of the tariffs considerably, it got into difficulties with achievement of cross border consensus in relation to these problems. The GATT functioned until 1994, when in 1995, a half of a century after the end of the Second World War and three quarters of the century after the Big Depression, it was renamed into World Trade Organisation (WTO) (Stiglics 2010: 23).

In 1973, the Bretton Wood Monetary System ceased to function (Latvijas 1982: 2.sējums 134). Taking into account that the US dollar began to lose, rapidly, its role as a means of international payments, the USA interrupted, in 1971, one-sidedly, the exchange of the dollar against gold. With breakdown of the Bretton Wood Monetary System (19711973), there ceased to exist also the official gold market and the centralized gold reserves of the states could reach the free market only (Vēciņš 1993: 136).

In 1978, the Jamaica Monetary System began to regulate the monetary and financial relations on a global scale (Latvijas 1982: 2.sējums 134). The Jamaica Monetary System was established in 1976 in Kingston (Jamaica) on the basis of the agreement related to the reform of international monetary system and attained by the International Monetary Fund (IMF). 
Today, the WTO, IMF and WB are important players in the management of the global economy, on which there depends the support for the countries, having got into difficulties. The WTO acts on a global scale to provide liberalisation not only in the trade, but also in other spheres, such as, for example, the regulation of the foreign investment and the protection of intellectual property. The IMF is responsible for accession of the finances by the countries, which have to solve their shortterm problems, but the World Bank answers for the long-term investments (Čangs 2011: 53).

The results of the activities of the mentioned above as well as of the other organisations depend, to a great extent, on the political system of the country.

\section{Political Competition of the Systems}

The implications of the Second World War had changed the economic situation in the Europe significantly. In the post-war period, there formed a dangerous and aggressive socialistic camp in the East of the Europe - the USSR , on the basis of pre-war agreements between the USSR and the Germany (Molotov-Ribbentrop Pact), in result of which a number of the countries, the members of the League of Nations (inter alia Latvia, Lithuania, Estonia), lost their independency, but during the post-war period, because of maintaining of the soviet army in the occupied East European countries, there took place the victory of socialist revolution in them, and, as a result, they were changed into satellite states of the socialist system.

In January, 1949, the socialist bloc countries established the Council for Mutual Economic Assistance (CMEA) - an international intergovernmental organisation of a multilateral economic cooperation between the socialist countries (Politiskā 1987: 602). It was a political challenge to the West, because the ideas of a worldwide revolution, with the USSR as the ideological driving force, got strength rapidly. The answer from the Allies to such challenges came soon. On the April 4, 1949, in Washington, 12 countries instituted the North Atlantic Treaty Organization (NATO) (Politiskā 1987: 756). The NATO was established as a counteraction to the USSR to block the enlargement of the influence zone of the USSR in the Europe, as well as further of the world.

For strengthening of the economic cooperation, 6 European countries established the European Coal and Steel Community (ECSC), in the1951, to solve the problems related to a rational location of production capacities, to facilitate the modernisation of the industry and the increase of productivity, as well as to regulate the competition. However, its principal aim was to unite the control over the main strategic coal and steel industries of the member states, mainly the France and the West Germany, to provide that the war between the member states would be impossible. In March, 1957, the six countries of the ECSC - the Federative Republic of Germany, the France, the Italy, the Belgium, the Netherlands, and the Luxembourg, entered into the Rome agreement treaty on establishment of the European Economic Community (EEC) and the European Atom Energy Community ("Euratom"). On the July 1, 1967, the Merger Treaty, related to uniting of these institutions into the European Community, came into force. In 1992, the European Economic Community changed into the European Union (EU).
Also in the military sphere, the two political systems demonstrated their power. On May 14, 1955, eight socialist states established the military Warsaw Treaty Organisation (Politiskā 1987: 731). The signing of the Warsaw Treaty in May, 1955, may be regarded as the East Block's answer to the accession of the Federative Republic of Germany to the NATO military alliance, because the Warsaw Treaty union was established in a week after this event.

During the post-war period, the relationship between the two competitive systems of the world (the socialism and the capitalism) continued to escalate and get up not only in the Europe, but also on the global scale. After the Second World War, in 1945, two super powers - the USA and the USSR developed. The countries, collaborating with the USA were called the West Block countries, but territories controlled by the USSR - the East Block countries. The representatives of the most powerful countries of the world had to understand that the USSR would not give up the spread of the ideology related to a worldwide socialist revolution. Also Stalin was not going to bring out the soviet army from the occupied countries, but continued to carry out the policy of socialism victory walk in the Europe and in the world.

As the beginning of the Cold War is regarded the March 5, 1946, when the former Prime Minister of the Great Britain, Winston Churchill, speaking in Fulton (USA), announced that an "iron curtain" had been dropped between the USSR and the rest of the Europe. In his turn, the President of the USA, Harry Truman, aiming to help the Greece and the Turkey to overcome the threats of communism, announced, on the March 12, 1947, that his country would support free nations, opposing to subjection. This announcement, having gone down into the history as the "Truman Doctrine", introduced curb tactics of communism expansion into the foreign policy of the USA. In their turn, the developments between the victorious countries continued to expand already in the territory of the Germany. On the May 23, 1949, on the basis of the occupation zones of the USA, the Great Britain and the France, the Federative Republic of Germany (FRG) was established, but on the October 7, 1949, in the occupation sector of the USSR, the Democratic Republic of Germany (DRG) was established. On the May 26, 1952, the Government of the DRG closed the border and established the borderland between the both parts of the Germany and the Berlin, but, at night of the August 13,1961 , the army troops of the DRG started building of the Berlin wall, which was pulled down only on the November 9, 1989. Together with the fall of the Berlin wall and merging of both German states, the decline of existence of communism ideology and of its introducer - the USSR, took, in point of fact, its start.

Also on the global scale, the world continued to split into two parts. On the September 2, 1945, the Democratic Republic of Vietnam was proclaimed. In the territory of Vietnam, there began a war (1946-1954), which continued, with some interruptions, from the 1955 even until the 1975. In September 1948, the Korean National Democratic Republic was proclaimed. The Korean War broke out and continued from 1950 to 1953. In October 1949, the Chinese Democratic Republic was proclaimed.

Although, during the post-war period, as a result of different events, the socialist ideology continued to be 
adopted by a range of new countries, however, after the death of Stalin (March 5, 1953), the social and national liberation attempts began to take place not only in the USSR, but also in the satellite countries controlled by the USSR. In summer of the 1953, a mass strike of political prisoners began in forced labour camps of political and special regime, established in Vorkuta city area, a remote Northern Arctic zone, the cause of which was the Decree of the Supreme Council on amnesty that was attributed to different categories of prisoners, but not to the political prisoners, regarded still as being dangerous to the political ideology of the USSR. In the middle of the June 1953, the impressive labour rebellion in Pilzen, Czechoslovakia, was bloody suppressed by the tanks of the Prague communist regime. Some days later, on the June 17, 1953, the first biggest national rebellion in the socialist encampment took place in the capital of other satellite of the USSR - the DRG.

On the October 23, 1956, with shooting at a peaceful student demonstration in the Budapest, there took the beginning the Hungary rebellion of the 1956. In Budapest, the Stalin sculptures were overturned and the soviet symbols torn off. However, the Hungarian Army changed the sides. The new Hungarian Prime Minister, Imre Naǵs, announced about the leaving of the Warsaw Treaty block. However, on the November 4, additional soviet army forces came into the Hungary, and an armed suppression of the national movement began, which ended with the suppression of national selfdetermination rights by the occupation state on the November $10,1956$.

The manifested by the USSR ideas of a Worldwide Revolution found a fertile sole also in the America. In 1959, Fidel Castro came to power in the Cuba and declared that he is a Marxist and protector of the socialist ideas. In the May, 1961, F. Castro announced that Cuba is a Socialist Republic. In result of such announcement, the diplomatic relations between the USA and the neighbouring Cuba, being only 90 miles from the Florida, became strained dramatically. In its turn, the USSR, being concerned that the nuclear arsenal of the USA was located in the territory of the Turkey, i.e. 150 miles from the border of the USSR, was interested in the balance of forces to its favour. To defend the socialist Cuba against a possible invasion of the USA, the leader of the USSR, N. Hrušcov, accepted, in the summer of the 1962, the plan of installing of soviet rockets in the Cuba. In 1962, the relations between the USSR and the USA culminated in such degree that could lead to a nuclear war. In the history, the intensity of this conflict is described as the Cuban or Caribbean conflict. During the Caribbean (Cuban) crisis, the contrariety of the social systems intensified to a white heat that was one of the most serious threats to the peace in the world since the Korean War. As it is well known, during the period 1961-1972, there was no one meeting of the leaders of the USA and the USSR.

\section{Ideological Struggle of the Systems}

The success of the USSR in conquering of space created a contemplation in the population about the long-term existence of the socialist system, notwithstanding that wages were not paid, the social security system of population as good as did not exist. During the Cold War, all possible funds were channelled to financing of the military industrial complex. During the Cold War, there took place a competition in creation of new weapons of mass destruction, the use of which might be able to influence not only several nations or countries, but the further existence of the whole humanity. The competition of social systems took place also in the ideological campaign. In the beginning of the 1960s, the USSR announced that, in 1980 s, its population would live in the communism. In 1961, the soviet press published the text of the project of the Programme of the communist party that promised that the today soviet people generation would live in the communism.

In the case of Latvia, the reflection of such ideology may be observed in the information of that time, being published by the press, propagated and disseminated otherwise. Fifty years ago, the readers of the magazine 'Zvaigzne' (January 5, 1962) could find in the article "Vārds 198\%.gadam!" a description of the benefits of socialism and the prognosis of development of communist life standard and to find out that in the 1980s the soviet people will live in communism. The editorial board, preparing the commentary, in the form of an anonym reportage and interview, had, in the introduction of its paper, written the following: "1981! What are we feeling, pronouncing this number? Impatience? Appreciation? Perhaps all of it? We know - that much of it all, being only intended and planned today, will be then implemented long ago already. The Soviet Country will be way ahead of America. ... Every family will have an individual, comfortable flat. We will have the shortest working day, the best supply, the highest social life culture, and the highest life standard in the world. We will have much of that we cannot even fancy today, because the life developed by communists is richer than the most adventurous fantasy. And yet - everybody of us desires to have a closer look at the future. Therefore we give the word to nineteen eighty one!" The publication mentions that the communication between the cities will be maintained by missile planes. The flight from Riga to Moscow will take fifteen minutes. The Baltic Sea will be turned into a freshwater lake, because several dams in Denmark will zone it off from the cold and salty North Sea. Because of the climate changes, the holidaymakers will stay in Riga Jürmala longer, the harvest in fields will not get wet, but, instead of strawberries, the grapes will be cultivated. Of course, publications may provide also a great many of fantasies to influence people ideologically.

Irrespectively the fact that, since September 22, 1921, the Republic of Latvia was a member state of the League of Nations, the government of the independent Latvia concluded, in the 1939, a treaty with the USSR that provided the possibility to locate military basis and a contingent of army troops of the USSR in the territory of Latvia that, for the Republic of Latvia, was the most essential mistake in strategic development of an independent state. In relation to the Russian - Finland War, the USSR was, in 1939, excluded from the League of Nations. In their turn, the inhabitants of the independent Latvia, having, in result of Molotov-Ribbentrop pact, got into the influence zone of USSR, experienced the June 17, 1940, when the USSR occupied Latvia. On the June 14, 1941, the first deportation of inhabitants took place, but in the March (25-28), 1949, before the beginning of the collectivisation, there was the second deportation - the deportation of the enemies of the socialist system. A deportation to Siberia of creative intelligentsia, politicians, deputies of the Saeima of Republic of Latvia and the self-governments, leaders of the political parties, officers and other Latvian people of different 
nations took place, irrespective of the promise that, with the collectivisation, the lifestyle of the farmers in Latvia would not be deranged. However, the deportation of the people to the USSR created a fear to the population that did not vanish from their memory up to the 1991 - the restoration of independence of Latvia.

Also in the socialism camp - in the Czechoslovakia Socialist Republic, in the middle of 1960 s, the communist regime became more and more unpopular. In order to create "socialism with a human face", on January 5, 1968, Alexander Dubček was elected the leader of the Communist Party, and in April, 1968, the so called Programme of Action was proclaimed. It was a totality of several reforms and plans. Although Dubček's initiatives got a vast support of the population, yet the leadership of the USSR, with Leonid Brežnev at the head, perceived them as the first steps of derange of the soviet system. The leadership of the USSR could not tolerate that during the Cold War one of its satellites moved to Western democracies. In the night from the August 20 to 21, 1968, five states of the Warsaw Pact invade into Czechoslovakia. As a result, Dubček was arrested by soviet armed forces and taken to Moscow.

\section{Insight into the Course of Politico-Economic Developments}

From the Great depression the USA was led out by the New Deal carried out by the President Franklin Roosevelt and his administration. On the basis of reforms, the US dollar was freed from the gold standard, the introduction of a strong economy regime in the financial area was started all over the country, a progressive tax system was introduced, the state organized large building projects of infrastructure, successfully was solved the diminishing of debt burden of bank debtors, the rights of trade unions were strengthened, the minimal wage introduced, the maximal length of working day defined, the social security system (supports, pensions, health insurance and others) introduced. The course, carried out in result of the reforms in the USA, bore fruit, and was the main sponsor of the economies of the European countries destroyed during the war (Marshal Plan) and, at the same time, the most serious competitor (Judrupa, I., 2007: 20-23). The main principles of the New Deal, based on the use of protective mechanisms of the inner markets of the countries, provided economic growth impulse for the countries of the world in both the West and the East. This model is characterized by a mixed economy (large public or state and self-government sector, private sector and cooperation), progressive tax system, strong regulation of financial area and social infrastructure, social guarantees, guaranteed, state subsidized health care and education, strong trade unions, state responsibility for welfare of all citizens and human rights, democracy. Such system provided a sufficiently high employment level, equalized the stratification tempos of population and facilitated solitaire development of the society (Galbraith, J.K., 1994).

The inability of one of the classical advocates of the "Gold Standard", the Great Britain, to hold the gold as the measure of the currency value of the countries, led to the use of this situation in its own interests by the former British colony the United States of America, having suffered relatively small losses during the Second World War, but profited well on account of the warring countries, through financing their expenses, created by the war, and, as a result, the warring countries had been turned into debtors of the USA.

The after-war currency system created great advantages to the USA, because, if other countries were, for covering of their foreign debts created by deficits of the balance of payments, pressed to set to their gold reserves or to restrict the consumption, and to facilitate the export, then the USA was able to repay their foreign debts in their inner currency, without taking into account the externals. In such way, it continued until the middle of the 1960s.

In 1971, the USA was no more able to convert dollars, i.e. to exchange them against gold. The trust to dollars and to the rate of their exchange diminished, and the Bretton Wood system collapsed. Since 1971, the states abandoned stable currency rates and turned to freely floating exchange rates. The crisis of the Bretton Wood monetary system began in the end of 1960s because of devaluation of the sterling pound of Great Britain. The Bretton Wood monetary system had served nearly 30 years as an international instrument of economic development. It was stimulated by the existence of a great number of economic contradictions and the instability, as well as by the cyclic crisis of the world. Also the increase of inflation made a negative impact on the prices and the competitiveness of the companies all over the world, resulting in instability of the exchange rate. The instability of the balance of payments of the countries (chronic deficit in the USA and Great Britain; an active balance in Germany and Japan) created a floating of the exchange rate. At the beginning, the Bretton Wood system was very stable, because all countries were in need of dollars; but, in the course of time, a "shortage of dollars" emerged. The breakdown of the Bretton Wood system led to the devaluation of the dollar. The confusion set in all over the international payments. At one and the same time, there existed the official and the free market exchange rates.

After the Second World War, the balance of payments of the USA began to worsen, as the dollars, in the form of different investment projects, inter alia, the Marshall Plan and loans, began to flow out of the USA. As a result, the negative balance of payments of the USA began to increase, and, in the 1970, it was even 10 billion USD. The deficit of the balance of payments meant a greater outflow of the dollars from the USA, followed by a decrease in gold reserves.

In other countries, a rapid increase in amount of dollars took place. The amount of dollars increased rapidly in Germany, as well as in France, Great Britain and Italy.

The changes in the power of the world were followed by:

- devaluation of the pound, 1967;

- devaluation of the franc of France, 1969;

- revaluation of the West Germany mark, October, 1969;

- devaluation of the dollar, 1971.

In 1971, the USA ceased, one-sidedly, the exchange of the dollar against gold, because the US dollar began to lose rapidly its role as a means of payment. In 1973, the Bretton Wood monetary system ceased to function (Latvijas 1982: 2. sējums 134). With breakdown of the Bretton Wood monetary system (1971-1973), the official gold market ceased to exist, and, after that, the centralized gold reserves of the countries could get into the free market only (Vēcinsš 1993: 136).

Since the 1978, the monetary and financial relations on the global scale began to be regulated by the Jamaica Monetary System Latvijas 1982: 2.sējums 134). The Jamaica Monetary 
System was created in the 1976 in Kingston (Jamaica) on the basis of the agreement achieved by the countries of International Monetary Fund (IMF) on the subject of reform of the international monetary system. With acceptance of the Jamaica Monetary System the Bretton Wood Monetary System ceased to exist.

The period from 1930s to 1980s may be called the period of a non-liberal policy in economics. Since 1980s, the nonliberal policy was abandoned in the world, and the neoliberalism appeared (Čangs 2011: 51).

In the post-war period, the reality got into contradiction to the economic theory of Keynes, being based on the importance of the role of the national states in regulation of the market processes.

As it is well known, the global economy experienced the crashes created by the financial economic crisis of the 1929-1933 (Galbraith, 1988). The theoretical justification for overcoming of the implications, created by the crisis, was provided by the British economist J.M. Keynes (1883-1946). In the book "General Theory on Employment, Interest and Money", published in 1936 (Keynes, 1947). John Maynard Keynes disclosed the causes of the Great Depression and developed methods for improvements of the economy. To this publication, his name is related as the founder of the Theory of Macroeconomics (Samuelson, P., 2010) . Before the terms Macroeconomics and Microeconomics were not used because a general concept Economics took place instead. Only in the 1941, a little known economist of the Statistical Institute of Netherlands, P. de Wolf, mentions it, for the first time, in one of his publications, attributing to Microeconomics the single persons or families, but to Macroeconomics - the large groups, various strata of society, and nations (Гукасьян, Г. M., 2001: 8).

If, after the Great Depression, the economic theory of Keynes revived the economic life of the countries, having experienced the crisis, than in the end of the 1960s the global economy faced new globalisation challenges.

In the 1970s, the ideas of monetarism (monetary policy) could be observed at the horizon, the basics of which were formulated in support to a free market economy that foresees a minimal interference of the state into economic relations (Krilovs L., 2009: 65). A new wave of liberalism or the neoliberalism appeared, proclaiming that the countries have to accept such rules of the play that are written by international organisations. It meant that the national states could no more participate actively in the regulation of the economic processes in their countries because of the possibility to come into the contact with trespass of a signed agreement (Keišs, S., Bramanis, D., 2011:170).

The founder of the monetary economic theory is the economist of the USA Milton Friedman (1912-2006), the Nobel Prize Laureate in economy. (Потапова, И.С., 1998: 112). Friedman was one of the most consequent advocates of the monetarism and the free market, in opposition to Keynesianism or the welfare state idea. The concepts of the monetary theory are based on the changes in the amount of the money, being regarded as the main cause of changing fluctuations in economic development. In result of regulation of the amount of the money, the price level, the income of the population and the employment become influenced, but the stabilization of the amount of the money in circulation provides also the stability of the economy on the whole (Ekonomikas 2003: 231).

\section{New Globalisation Challenges to the Economic Science since 1980s}

In the beginning of 1970 s, the economy of the world faced events, having been unforeseen previously. The first and the most important of them was the problem created by huge debts of the Third World (Bojārs, Vilne 1996:7).

Since the 1980s the non-liberal policy was, all in all, abandoned in the world, when the neo-liberalism appeared. In the end of the 1980s, the failure of so called import substitutions in industrialisation (ISI), based on protectionism, subsidies and regulations, had become too obvious, in the developing countries, to be ignored. The idea of import substitutions in industrialisation means that an underdeveloped country begins itself to produce the products, being, previously, used to be imported, replacing, in such way, the imported industrial products by local equivalents. It could be achieved artificially, making the import more expensive through the tariffs and import quotas or the subsidies to local producers. In the 1930s, this strategy was accepted by a number of Latin America countries. In that time, most of the developing countries were not able to practise the strategy of ISI, because they were either colonies or subjected to "unequal agreements", prohibiting them to determine the tariffs. The ISI strategy was adopted by most of the developed countries after obtaining independence, from the middle of the 1940s to the middle of the 1960s (Čangs 2011: 51-52). The East Asian economic "miracle" that already practised the free trade and was opened to foreign investments, was like an alarm-clock to other countries. After the third debts crisis in the 1982, a number of developing countries abandoned the state interference and protectionism and adopted neo-liberalism. These tendencies, oriented to a global integration, were crowned by the collapse of communism in 1989 (Čangs 2011: 52).

In the official globalisation history, the earlier period after the Second World War is reflected as an imperfect globalisation time. While, among the rich countries, the integration developed essentially, accelerating their growth, most of the developing countries refused fully, till $1980 \mathrm{~s}$, to take part in the global economy, so abstaining from economic progress (Čangs 2011: 56-57).

\section{Neo-liberalism}

Neo-liberalism is interpreted as a discipline that supports the free market, a minimal interference of the state into economic relationship, as well as private property rights (Бартенев, С.A., 2000: 161). The economist Bred Delong indicates to the two basic principles of neo-liberalism; they are: a close contact between the developed and developing countries that is the best way, how to accelerate the movement of technologies. It is the main precondition to provide that the poor countries could become well-off; all in all, the governments lack the ability to manage big industrial and commercial companies, therefore the state administration must be scaled down and it must fulfil the most essential tasks - distribution of income, governing of judicial system, provision of public benefits and others. The other sectors must be privatized (Delong, J.B., 2000). 
As one of the brightest basics of the neo-liberalism, there is mentioned the principle, elaborated in the 1970s during the New York crisis, and used later, for the first time, internationally, during the Mexico crisis, in the 1982, i.e. that the state has, at all costs, to protect the financial institutions. With the aim to rescue the New York investment banks, during the Mexico crisis, the IMF and the Treasury of the USA joined into a guarantee for the Mexico. Wherewith, there was started, for the first time, the approach that these institutions provided a loan to the government (Demokratijas, 1993: 47; Harvey, D., 2009).

Beginning with the 1982, the IMF provides the lending on condition that the countries, having got into problems, accept only such policy as the liquidation of the deficit, the tax increase and the increase of the interest rates that causes a shrinking in economic growth of the country, as it is mentioned by Stiglics (Stiglics 2010: 20).

The ideas and initiatives related to creation of international economic institutions were good; however, in the length of time, they changed, gradually, into a fully different kind of institutions. The Keynesian orientation of the IMF that accentuated the market failure and the role of state in creation of working places was replaced by the market mantra of 1980s, a part of "Washington Consensus" - the agreement between IMF, World Bank and Treasury of the USA on the subject of the "right policy" of the developing countries that proclaimed a sharply different approach to development and stabilisation of economy (Stiglics 2010: 23).

A lot of ideas, included in it, were developed as the answer to the problems of the countries of Latin America, where the governments had let the budget out of hands, and the free monetary policy had created a wild inflation. In some countries of the Latin American region the achieved, after the Second World War, economic growth became exhausted, as if because of the excessive interference of the state into the economy. But the ideas that were developed, say, for solution of the specific problems of the countries of Latin America, were afterwards accepted as suitable by the countries all over the world (Stiglics 2010: 23). Despite the lack of evidences, the liberalization of the capital market became realized as the only solution related to acceleration of economic growth of the country. Stiglics remarks that the economic policy, being the basis of development of the Washington consensus, and introduced by the developed countries, turned out as inappropriate to the countries in their early development or transition stage (Stiglics 2010: 23).

For example, the majority of industrially developed countries, as well as the USA and Japan, had developed their economy on the basis of a clever and selective protection of some production industries as long as they became strong enough to compete with foreign companies. Although the all-embracing protectionism has not always functioned in the countries, having tried to use it, similarly as unsuccessful has also turned out a too rapid liberalisation of the trade. In case of pressing of developing countries to open their market to imported products that compete with products of certain industries, such ones that are dangerously sensitive according to competition of more powerful rivals from other countries, may lead to catastrophic implications in both areas the social and the economic. In developing countries, there takes place a systematic wiping out of working places; the poor farmers are not, simply, able to compete with subsidised products of the Europe and the America, before the industrial and agricultural sector had not been in capacity to become stronger and create new working places (Stiglics 2010: 23-24).

According to approved history, the neo-liberalism policy that was realised during this period and the events, related to it, are the result of developments of the global economy of the world. Because of the potential of liberalism and welfare, it is to be compared even with "the golden era" of liberalism (1870-1913) (Čangs, H., 2010: 11). To find answers to the questions, remaining still unanswered, it is necessary, in economic theory, to carry out studies of globalisation and market development processes.

\section{Conclusion}

Under globalisation conditions, the market processes and problems of social economic development influence, in one way or another, all countries of the world. The evaluation of this influence and making use of its positive sides and the avoidance of the negative ones depend on the condition how far the development of the economic thought keeps step with the challenges of globalisation. Otherwise, the coming into being of a line of surprises and wrong explanations are unavoidable that may lead to undesirable implications.

It is evidenced by several striking examples. If in the beginning of the $20^{\text {th }}$ century, there dominated, in the economic theory, the thought that all misfortunes of the society were caused by the crises of the overproduction, then, in the end of the $20^{\text {th }}$ century, the society was subjected to the experience of the implications of excessive overconsumption crises. In the end of the $20^{\text {th }}$ century and in the beginning of the $21^{\text {st }}$ century, even the national states had got into solution of insolvency problems, borrowing the money, inadequately, in the domestic and international markets. In the first decade of the $21^{\text {st }}$ century, this tendency affected, especially painfully, also some countries of the EU. Similarly, it is with the events in the Ukraine, if we look in the context of the globalisation. It leads to the conclusion, that the reason is to be sought in the circumstance that, there is, as regards the development processes of the society, taking place insufficient attention to the topicality related to the study of economic regularities. If the society would be functioning normally, i.e. accordingly to adequate scientific concepts, then there could not be created a situation that, on the global scale, the politicians decide on the problems that are related to satisfying of the needs of the society.

In economic theory, the discussion, involving economic laws, became exhausted during the period from the First World War to the Second World War. Instead of it, the economic science fell apart into Microeconomics and Macroeconomics, where there, as a norm, was adopted the concept of a cyclic development of economy. If we respect the laws of the nature and are not going to contradict them, it should be used the same attitude according to the laws of development of the society. It is time to return to fundamental researches in the economic science. Without such researches, it is impossible to come to a balanced development that is free of cyclic crashes of the crises. Also the wars and the annexation of foreign territories form not the way to increase the wealth of a nation.

It is important for every country to find, in the due time, its best way for a further development, taking into consideration 
all inner and outer processes and their interaction. Especially important the interaction of these processes turns out to be in the small countries, because they must be prepared to react adequately to the developments, taking place in the big countries.

In relation to the small countries, including Latvia, as a special problem, related to seeking for solution in the globalisation context, may turn out their history, especially, for the period of involvement into the structure of the USSR, because it may be, not always, understandable for the representatives of the Western countries.

The assistance in understanding of the public processes and the development of economic thought of the post-socialism countries may provide, first of all, the scientists, having lived under conditions of the centralized command economy or carried out researches related to these problems. Therefore, as a topicality, there has become fundamental, theoretical and practical researches in ones own country, cooperating, in this area, with other post-socialism countries and the Western countries.

\section{References}

„Vārds 1985 gadam!’ Žurnāls „Zvaigzne”, 1962.gada 5.janvāris, Nr.1, 5-6 lpp.

Bojārs, J., Vilne V., 1996. Starptautiskās investīcijas. LU Starptautisko attiecību institūts. Rīga, 1996. - 265 lpp.

Deksnis, E. B., 1996. Eiropas Savien̄iba, mīti un īstenība. Junda, Rīga, 192 lpp.

Delong, J.B., 2000. Globalization and Neoliberalism http:// econ161.berkeley.edu/Econ_Articles/Reviews/alexkafka. html

Demokrātijas pamati. 1993. Zinātne, Rīga, 47 lpp.

Ekonomikas un finanšu vārdnīca, 2003. Apgāds Norden AB Rīga, 514 lpp.

Galbraith, J.K., 1988. The Great Crash, 1929. Houghton Mifflin Company, Boston, 206 p.

Galbraith, J.K., 1994. A Journey Through Economic Time. Houghton Mifflin Company, Boston, 255 p.

Hadžūns, Č., 2011. Sliktie samarieši. No angḷu valodas tulkojis Pēteris Treijs. Apgāds „Zvaigzne ABC”, Rīga, 384 lpp.

Harvey, D., 2009. Is This Really the End of Neoliberalism? http://www.counterpunch.org/harvey03132009.html
Judrupa, I., 2007. Eiropas valstu ekonomika. RTU Izdevniecība, Rīga, 332 lpp.

Keišs, S., 2012. Challenges of Globalization to Economics Science and Latvia. Journal: Economic and Culture \& Ekonomika un kultūra. Ekonomikas un kultūras augstskola. Rīga Vol.5. pp. 51-66.

Keišs, S., Bramanis, D., 2011. Latvian Regional Development in the Context of Global Economy. Journal: Economics and Culture \& Ekonomika un kultūra. Rīga Vol.3. pp. 160-180.

Keynes, J. M., 1947. The General Theory of Employment, Interest and Money. Macmillan and CO, London, 403 p.

Krilovs, L., 2003. Ekonomiskās domas vēsture. Lekciju konspekts, I daḷa. RTU izdevniecība, Rīga, 216 lpp.

Krilovs, L., 2008. Ekonomiskās domas vēsture. Lekciju konspekts, I daļa. RTU izdevniecība, Rīga, 44 lpp.

Krilovs, L., 2009. Ekonomiskās domas vēsture. Lekciju konspekts, III daḷa. RTU izdevniecība, Rīga, 105.lpp.

Kučinskis, J., 2000. Jaunā pasaules kārtība un mēs paši. Jēkabpils, 349 lpp.

Latvijas Padomju enciklopēdija. 1984, 5.1.sējums. Galvenā enciklopēdiju redakcija. Rīga. 762 lpp.

Latvijas Padomu enciklopēdija. 1982, 2.sējums. Galvenā enciklopēdiju redakcija, Rīga. 732 lpp.

Politiskā enciklopēdija. 1987. Galvenā enciklopēdiju redakcija, Rīga, 780 lpp.

Samuelson, P., 2010. Economics. 19th ed. New-York: McGraw-Hill, 715 lpp.

Stiglics, Dž. J., 2010. Globalizācija un neapmierinātība ar to. SIA „Biznesa augstskola Turība”, Rīga, 246 lpp.

Šreters, H.J., 2004. Eiropas Savienības leksikons. Politika. Ekonomika. Vēsture. Kultūra. Tulkots no vācu valodas. Jumava, Rīga. 267 lpp.

Vēcinsš, Ē., 1993. Naudas lietas. Skaidrojošā vārdnīca. Zvaigzne, Rīga, 170 lpp.

Бартенев, С.А., 2000. История экономических учений 8 вопросах и ответах. Юуристь, Москва, 192 с.

Гукасьян, Г.М., 2001. Экономическая теория: ключевые вопросы: Учебное пособие. Под ред. д.э.н.

Добрынина А.И.. 3-е изд., доп. ИНФРА-М, Москва, 199 lpp.

Потапова, И.С., 1998. История экономических учений. Учебное пособие. МГИУ, Москва, 233 с.

The article has been reviewed. Received in April, 2014; accepted in June, 2014. 